\title{
PENGARUH PENGGUNAAN SUMBER BELAJAR DAN KOMUIKASI INTERPERSONAL TERHADAP HASIL BELAJAR PENDIDIKAN KEWARGANEGARAAN
}

\author{
Yeni Rasita Pini Ketaren \\ Guru SMA Negeri 1 Padang Tualang, Kabupaten Langkat, Sumatera Utara \\ yenirasita_pini@gmail.com
}

\begin{abstract}
Abstrak: Penelitian ini bertujuan untuk mengetahui dan mendeskripsikan: (1) Hasil belajar PKn siswa yang diajar dengan menggunakan sumber belajar Internet dan siswa yang diajar dengan menggunakan Buku ajar; (2) Hasil belajar PKn antara siswa yang memiliki komunikasi interpersonal tinggi dengan siswa yang memiliki komunikasi interpersonal rendah; dan (3) Interaksi antara sumber belajar dan komunikasi interpersonal siswa terhadap hasil belajar PKn. Penelitian ini adalah penelitian kuantitatif dengan jenis penelitian kuasi eksperimen disain faktorial 2x2. Hasil penelitian menunjukkan bahwa: (1) Hasil belajar PKN Peserta Didik yang Diajar Dengan Menggunakan Sumber belajar Dengan Menggunakan internet Lebih Tinggi Dibandingkan dengan Peserta Didik yang Diajar Menggunakan Sumber belajar Dengan Menggunakan Buku Ajar; (2) Hasil belajar PKN Peserta Didik yang Memiliki Komunikasi Interpersonal Positif Lebih Tinggi Dibandingkan dengan Hasil Belajar PKN Peserta Didik yang Memiliki Komunikasi Interpersonal Negatif; dan (3) Terdapat interaksi antara Sumber belajar dan Komunikasi Interpersonal Dalam Mempengaruhi Hasil Belajar PKN Peserta Didik.
\end{abstract}

Kata Kunci: sumber belajar, komuikasi interpersonal, pendidikan kewarganegaraan

Abstract: This study aims to find and describe: (1) The results of learning Civics students are taught by using Internet learning resources and students are taught by using textbooks; (2) Civic learning outcomes between students who have high interpersonal communication with students who have low interpersonal communication; and (3) the interaction between the learning resources and the students' interpersonal communication toward the Civics learning outcomes. This research is quantitative research with quasi experimental research type $2 x 2$ factorial design. The results showed that: (1) Learning outcomes of PKN Educated Learners Using Learning Resources Using Higher Internet Compared to Educated Learners Using Learning Resources Using Textbooks; (2) Learning outcomes of PKN Educative Participants with Higher Positive Interpersonal Communication Compared with Learning Outcomes of PKN Learners Who Have Negative Interpersonal Communication; and (3) There is an interaction between learning resources and interpersonal communication in influencing learning outcomes of PKN learners.

Keywords: learning resources, interpersonal communication, civic education

\section{PENDAHULUAN}

Belajar merupakan suatu proses yang kompleks yang terjadi pada diri setiap orang sepanjang hidupnya. Proses belajar itu terjadi karena adanya interaksi antara seseorang dengan lingkungannya. Oleh karena itu, belajar dapat terjadi kapan saja dan dimana saja. Pada intinya, tujuan utama setiap proses pembelajaran adalah diperolehnya hasil yang optimal, termasuk dalam belajar Pendidikan Kewarganegaraan.

Tujuan utama diselenggarakannya proses belajar adalah demi tercapainya tujuan pembelajaran, dan tujuan tersebut utamanya untuk keberhasilan siswa dalam belajar, baik pada suatu mata pelajaran tertentu maupun pendidikan pada umumnya. Dalam upaya lebih mewujudkan fungsi pendidikan sebagai wahana sumber daya manusia, perlu dikembangkan iklim belajar mengajar yang konstruktif bagi berkembangnya suasana, kebiasaan, dan strategi belajar mengajar yang dilandasi dengan kepahaman tentang ilmu-ilmu pengetahuan serta implikasinya dalam kegiatan belajar mengajar bagi para guru di sekolah.

Dalam peningkatan hasil belajar Pendidikan Kewarganegaraan, sumber belajar yang dapat dipergunakan oleh guru pada proses 
belajar mengajar mencakup sumber belajar yang dirancang berupa buku ajar dan sumber belajar yang dimanfaatkan berupa sumber belajar yang berasal dari internet. Sumber belajar yang dirancang merupakan sumbersumber belajar yang secara khusus di kembangkan sebagai "komponen sistem instruksional" yang diharapkan dapat membantu kemudahan kegiatan belajar yang bersifat formal ataupun non formal dan mempunyai tujuan tertentu. Buku ajar sebagai sumber belajar yang dirancang merupakan materi pembelajaran yang disusun secara sistematis yang digunakan guru dan siswa dalam proses pembelajaran. Buku ajar mempunyai struktur dan urutan yang sistematis, menjelaskan tujuan instruksional yang akan dicapai, memotivasi siswa untuk belajar, mengantisipasi kesukaran belajar siswa sehingga menyediakan bimbingan belajar siswa untuk mempelajari bahan tersebut, memberikan kesempatan latihan bagi siswa, menyediakan ringkasan, dan secara umum berorientasi pada siswa secara individual (learner oriented).

Torkleson (1965) menyatakan bahwa sumber belajar adalah segala sesuatu yang di gunakan untuk kepentingan pelajaran yaitu segala yang ada di sekolah pada masa lalu, sekarang dan yang akan datang. Definisi ini mementingkan kata kepentingan pelajaran yang menunjukkan bahwa sumber belajar dan pemanfaatannya adalah memberdayakan berbagai sumber, tidak hanya terbatas pada buku atau alat-alat yang dapat di dengar dan dapat di lihat saja, namun sesuatu yang dapat di manfaatkan untuk menunjang kegiatan belajar.

Lebih lanjut menurut Sudjana (2004) sumber belajar adalah segala daya yang dimanfaatkan guna memberi kemudahan kepada seseorang dalam belajarnya. Atau dalam proses pembelajaran baik secara langsung atau tidak langsung, sebagian atau secara keseluruhan. Menurut Sri Anitah (2008), sumber belajar adalah segala sesuatu yang dapat digunakan untuk memfasilitasi kegiatan belajar. Berkaitan dengan sumber belajat menurut Pawit M. Yusuf (2010), sumber belajar adalah segala jenis media, benda, data, fakta, ide, orang, dan lain lain yang dapat mempermudah terjadinya proses belajar.

Seels (1994) menyatakan bahwa sumber belajar mencakup apa saja yang dapat digunakan untuk membantu tiap orang untuk belajar dan orang tersebut dapat menampilkan kompetensinya. Sedangkan AECT (2004) mengartikan sumber belajar sebagai semua sumber (data, manusia, dan barang) yang dapat digunakan siswa sebagai suatu sumber tersendiri atau dalam kombinasi untuk memperlancar belajar. Dalam hal ini sumber belajar meliputi pesan, orang, material, alat, teknik, dan lingkungan.

Internet singkatan dari interconnection and networking. Internet adalah jaringan informasi global terbesar yang memungkinkan orang untuk saling berhubungan secara mudah dan cepat melalui teknologi terutama Personal Computer (PC). Internet diluncurkan pertama kali oleh J.C.R. Licklider dari Massachusetts Institute Technology (MIT) pada bulan Agustus 1962. Istilah internet jika diterjemahkan secara langsung berarti jaringan yang saling terhubung. Internet sendiri merupakan gabungan jaringan komputer di seluruh dunia yang membentuk suatu sistem jaringan informasi global.

Sumber belajar yang dimanfaatkan yaitu sumber-sumber yang tidak secara khusus didesain untuk keperluan pembelajaran namun dapat di temukan, diterapkan, dan digunakan untuk keperluan belajar.

Dari beberapa definisi dan penjelasan tentang teknologi instruksional dapat diambil beberapa kesimpulan bahwa teknologi instruksional menghasilkan sumber belajar yang dapat digunakan untuk memperbaiki pengajaran. Terdapat fungsi-fungsi tertentu, misalnya pengembangan instruksional, produksi media, pengelolaan sumber belajar, penilaian program, dan sebagainya yang harus dijalankan oleh tenaga-tenaga tertentu dalam bidang teknologi instruksional.

Internet sebagai sumber belajar yang dimanfaatkan dapat memberikan fasilitas belajar bagi siswa karena internet adalah jaringan informasi komputer mancanegara yang berkembang sangat pesat dan pada saat ini dapat dikatakan sebagai jaringan informasi terbesar di dunia, sehingga sudah seharusnya para profesional mengenal manfaat apa yang dapat diperoleh melalui jaringan ini.

Proses belajar dikelas yang menggunakan internet sebagai sumber belajar diharapkan dapat menjadi bagian dari suatu proses belajar di sekolah, internet diharapkan mampu memberikan dukungan bagi terselenggaranya proses komunikasi interaktif antara guru dengan siswa. Kondisi yang perlu didukung oleh internet berkaitan dengan strategi pembelajaran yang akan dikembangkan, 
yaitu sebagai kegiatan komunikasi yang dilakukan untuk mengajak siswa mengerjakan tugas-tugas dan membantu siswa dalam memperoleh pengetahuan yang dibutuhkan dalam rangka mengerjakan tugas-tugas.

Semua komputer yang terhubung ke internet dapat mengakses semua informasi yang terdapat di internet secara gratis. Internet dapat digunakan sebagai sarana pertukaran informasi dari satu komputer ke komputer lain tanpa dibatasi oleh jarak fisik kedua komputer tersebut. Peranan internet yang sangat penting adalah sebagai sumber data dan informasi serta sebagai sarana pertukaran data dan informasi. Internet merupakan jaringan global yang menghubungkan beribu bahkan berjuta jaringan komputer (local/wide ared network) dan komputer pribadi (stand alone), yang memungkinkan setiap komputer yang terhubung kepadanya bisa melakukan komunikasi satu sama lain. Menurut Rosihan Ari Y (2008), bahwa kata Internet merupakan singkatan dari 'inter-network'. Arti dari istilah tersebut adalah bahwa internet terdiri dari jutaan komputer di dunia. Jutaan komputer tersebut saling terhubung satu dengan yang lain."

Di Indonesia, internet baru masuk pada sekitar awal 1990an. Itu pun berkat jasa ilmuwan Indonesia yang belajar ke luar negeri. Setelah mendapat ilmu tentang internet dan sekembalinya di Indonesia, para ilmuwan tersebut mulai menerapkan ilmunya dengan mengembangkan internet di Indonesia. Menurut Rosihan Ari Y (2008) "Browsing atau menjelajahi situs web memanfaatkan layanan internet khususnya www. www atau World Wide Web yang mulai dikembangkan pada tahun 1989 oleh Timothy Berners-Lee. Dengan www, orang bisa membuka halaman-halaman web dalam sebuah situs web.

Buku ajar sebagai sumber belajar yang dirancang adalah bahan-bahan atau materi pembelajaran yang disusun secara sistematis yang digunakan guru dan siswa dalam proses pembelajaran.

Menurut Muslich, buku ajar adalah buku yang berisi uraian bahan tentang mata pelajaran atau bidang studi tertentu, yang disusun secara sistematis dan telah diseleksi berdasarkan tujuan tertentu, orientasi pembelajaran, dan perkembangan siswa, untuk diasimilasikan. Pendapat yang sama juga disampaikan oleh Loveridge menyatakan bahwa Buku ajar adalah buku sekolah yang memuat bahan yang telah diseleksi mengenai bidang studi tertentu, dalam bentuk tertulis yang memenuhi syarat tertentu dalam kegiatan belajar mengajar, disusun secara sistematis untuk diasimilasikan".

Sedangkan Chambliss dan Calfee (1998) menyatakan buku ajar adalah alat bantu siswa untuk memahami dan belajar dari hal-hal yang dibaca dan untuk memahami dunia (di luar dirinya). Buku ajar memiliki kekuatan yang luar biasa besar terhadap perubahan otak siswa dan dapat mempengaruhi pengetahuan anak dan nilai-nilai tertentu.

Hakikat komunikasi adalah proses pernyataan antar manusia, yang dinyatakan itu adalah pikiran atau perasaan seseorang kepada orang lain dengan menggunakan bahasa sebagai alat penyalurannya. Menurut Cangara (2004), komunikasi adalah suatu proses dimana dua orang atau lebih membentuk atau melakukan pertukaran informasi dengan satu sama lainnya, yang pada gilirannya akan tiba pada saling pengertian yang mendalam.

Menurut Fachrunnisa (2008), komunikasi adalah proses dimana seseorang/kelompok/organisasi mengirimkan pesan kepada orang/ kelompok/ organisasi lain. Pihak yang mengirimkan pesan disebut pengirim pesan (sender), sedangkan pihak yang menerima pesan disebut dengan penerima pesan (receiver). Lubis (2008) menyatakan bahwa proses komunikasi adalah proses yang menggambarkan kegiatan komunikasi antar manusia yang bersifat interaktif, relasional, dan transaksional dimana komunikator mengirimkan pesan kepada komunikan melalui media tertentu dengan maksud dan tujuan tertentu. Defenisi komunikasi secara lengkap dinyatakan oleh Effendy (2003), komunikasi adalah proses penyampaian suatu pesan oleh seseorang kepada orang lain untuk member tahu atau untuk mengubah sikap, pendapat atau perilaku baik langsung secara lisan maupun tak langsung melalui media.

Kegiatan komunikasi dalam kehidupan manusia merupakan suatu hal yang sangat penting. Apa yang mendorong manusia sehingga ingin berkomunikasi dengan manusia lainnya, Effendy (2001) menyatakan bahwa teori dasar komunikasi menyebut adanya dua kebutuhan, yakni kebutuhan untuk mempertahankan kelangsungan hidupnya dan kebutuhan untuk menyesuaikan diri dengan lingkungannya. 
Hovland, Janis dan Kelly dalam Rakhmat (2004) mendefinisikan komunikasi sebagai "the process by which an individual (the cominicator) to modify transmits stimuli (usually verbal) to modify the behavior of other individuals (the audience)". Sementara Dance mengartikan komunikasi sebagai usaha menimbulkan respon melalui lambang-lambang verbal, ketika lambang-lambang verbal tersebut bertindak sebagai stimuli.

Komunikasi yang berlangsung terhadap diri manusia dapat terdiri dari beberapa macam. Tubbs dan Moss (2003) menyatakan secara umum ada 7 (tujuh) macam komunikasi, yaitu : (1) komunikasi interpersonal; (2) komunikasi intercultural; (3) komunikasi saling berhadapan; (4) komunikasi kelompok kecil; (5) komunikasi publik; (6) komunikasi organisasi, dan (7) komunikasi massa.

Masalah penelitian ini dapat dirumuskan sebagai berikut: (1) Apakah hasil belajar PKn siswa yang diajar dengan menggunakan sumber belajar Internet lebih tinggi daripada hasil belajar PKn siswa yang diajar dengan menggunakan buku ajar ?; (2) Apakah hasil belajar PKn siswa yang memiliki komunikasi interpersonal tinggi lebih tinggi daripada hasil belajar PKn siswa yang memiliki komunikasi interpersonal rendah?; dan (3) Apakah terdapat interaksi antara sumber belajar dan komunikasi interpersonal terhadap hasil belajar PKn?

\section{METODE}

Penelitian ini dilaksanakan di SMA Negeri 1 Padang Tualang dan SMA Negeri 1 Kecamatan Binjai Kabupaten Langkat. Populasi adalah totalitas semua nilai yang mungkin, hasil perhitungan atau pengukuran secara kuantitatif mengenai karakteristik tertentu dari semua anggota kumpulan yang lengkap dan jelas, yang ingin dipelajari sifat-sifatnya (Sudjana, 2002). Populasi penelitian ini adalah seluruh siswa kelas $X$ SMA Negeri 1 Padang Tualang dan SMA Negeri 1 Kecamatan Binjai Kabupaten Langkat. Siswa kelas X SMA Negeri 1 Padang Tualang dan SMA Negeri 1 Kecamatan Binjai masing-masing memiliki 4 (empat) kelas. Sampel merupakan sebahagian dari populasi yang dipilih secara representatif, artinya karakteristik populasi tercermin dalam sampel yang diambil (Sudjana, 2002). Teknik penarikan sampel dalam penelitian ini adalah Cluster Random Sampling. Teknik digunakan, jika dijumpai populasi yang heterogen dimana sub populasi merupakan suatu kelompok (cluster) yang mempunyai sifat yang heterogen.

Penelitian ini adalah penelitian kuantitatif dengan jenis penelitian kuasi eksperimen disain faktorial 2x2. Melalui disain ini akan dibandingkan pengaruh penggunaan sumber belajar internet dan sumber belajar buku ajar, terhadap hasil belajar PKn, ditinjau dari siswa yang memiliki komunikasi interpersonal tinggi dan komunikasi interpersonal rendah. Penggunaan sumber belajar internet dan buku ajar sebagai variabel bebas dan komunikasi interpersonal tinggi dan komunikasi interpersonal rendah sebagai variabel moderator. Perolehan hasil belajar PKn sebagai variabel terikat. Selanjutnya variabel dimasukkan di dalam disain penelitian sebagaimana Tabel 1 berikut :

Tabel 1. Rancangan Eksperimen Desain Faktorial 2 x 2

\begin{tabular}{|c|c|c|}
\hline \multirow{2}{*}{$\begin{array}{c}\text { Komunikasi } \\
\text { Interpersonal }(\mathrm{B})\end{array}$} & \multicolumn{2}{|c|}{ Sumber Belajar $(\mathrm{A})$} \\
\cline { 2 - 3 } & Internet $\left(\mathrm{A}_{1}\right)$ & Buku ajar $\left(\mathrm{A}_{2}\right)$ \\
\hline Tinggi $\left(\mathrm{B}_{1}\right)$ & $\mathrm{A}_{1} \mathrm{~B}_{1}$ & $\mathrm{~A}_{2} \mathrm{~B}_{1}$ \\
\hline Rendah $\left(\mathrm{B}_{2}\right)$ & $\mathrm{A}_{1} \mathrm{~B}_{2}$ & $\mathrm{~A}_{2} \mathrm{~B}_{2}$ \\
\hline
\end{tabular}

Keterangan:

A : Sumber Belajar

B : Komunikasi Interpersonal

$\mathrm{A}_{1} \quad$ : Internet

$\mathrm{A}_{2} \quad$ : Buku Ajar

$\mathrm{B}_{1} \quad$ : Komunikasi Interpersonal Tinggi

$\mathrm{B}_{2} \quad$ : Komunikasi Interpersonal rendah
$\mathrm{A}_{1} \mathrm{~B}_{1}$ : Hasil belajar PKn yang diajar dengan internet pada siswa dengan Komunikasi Interpersonal Tinggi

$\mathrm{A}_{1} \mathrm{~B}_{2} \quad$ : Hasil belajar PKn yang diajar dengan internet pada siswa dengan Komunikasi Interpersonal Rendah 
$\mathrm{A}_{2} \mathrm{~B}_{1}$ : Hasil belajar PKn yang diajar dengan buku ajar pada siswa dengan Komunikasi Interpersonal Tinggi

$\mathrm{A}_{2} \mathrm{~B}_{2}$ : Hasil belajar PKn yang diajar dengan buku ajar pada siswa dengan Komunikasi Interpersonal Rendah Teknik analisis data yang digunakan adalah teknik statistik deskriptif dan inferensial. Teknik analisis deskriptif digunakan untuk mendeskripsikan data, antara lain: nilai rata-rata (mean), median, modus, varians dan simpangan baku. Teknik statistik inferensial digunakan untuk menguji hipotesis penelitian, dimana teknik inferensial yang akan digunakan adalah teknik Analisis Varians dua jalur (disain faktorial $2 \times 2$ ) dengan taraf signifikan 0,05.

Sudjana (2002) menjelaskan sebelum Anava dua jalur dilakukan, terlebih dahulu dilakukan pengujian persyaratan analisis yang meliputi uji normalitas dan uji homogenitas. Uji normalitas menggunakan uji Liliefors, sedangkan untuk uji homogenitas digunakan Fisher dan Bartlett. Setelah melakukan pengujian persyaratan analisis, selanjutnya dilakukan pengujia Anava dua jalur, selanjutnya dilakukan uji lanjut menggunakan uji Scheffe.

\section{Hipotesis Statistik}

Untuk keperluan pengujian hipotesis, dirumuskan hipotesis statistik sebagai berikut:
a. $\quad$ Ho : $\mu A_{1}=\mu A_{2}$
$\mathrm{Ha}: \mu \mathrm{A}_{1}>\mu \mathrm{A}_{2}$
b. Ho: $\mu \mathrm{B}_{1}=\mu \mathrm{B}_{2}$
$\mathrm{Ha}: \mu \mathrm{B}_{1}>\mu \mathrm{B}_{2}$
c. Ho: $\mathrm{A}><\mathrm{B}=0$
Ho : $\mathrm{A}><\mathrm{B} \neq 0$

Keterangan:

$\mu \mathrm{A}_{1}=$ Rata-rata hasil belajar pendidikan kewarganegaran yang diajar dengan menggunakan sumber belajar internet

$\mu \mathrm{A}_{2}=$ Rata-rata hasil belajar pendidikan kewarganegaraan yang diajar dengan menggunakan sumber belajar buku ajar

$\mu \mathrm{B}_{1}=$ Rata-rata hasil belajar siswa dengan komunikasi interpersonal Tinggi

$\mu \mathrm{B}_{2}=$ Rata-rata hasil belajar hasil siswa komunikasi interpersonal Rendah

\section{HASIL PENELITIAN}

Pengujian persyaratan analisis data meliputi pengujian normalitas dan homogenitas varians populasi. Uji normalitas ini dilakukan untuk mengetahui sampel yang digunakan apakah berasal dari populasi berdistribusi normal atau tidak. Uji homogenitas dengan Uji $\mathrm{F}$ dilakukan dengan melihat homogenitas varians antara dua kelompok sampel yang berbeda.

Tabel 2. Rangkuman Data Hasil Perhitungan Analisis Deskriptif

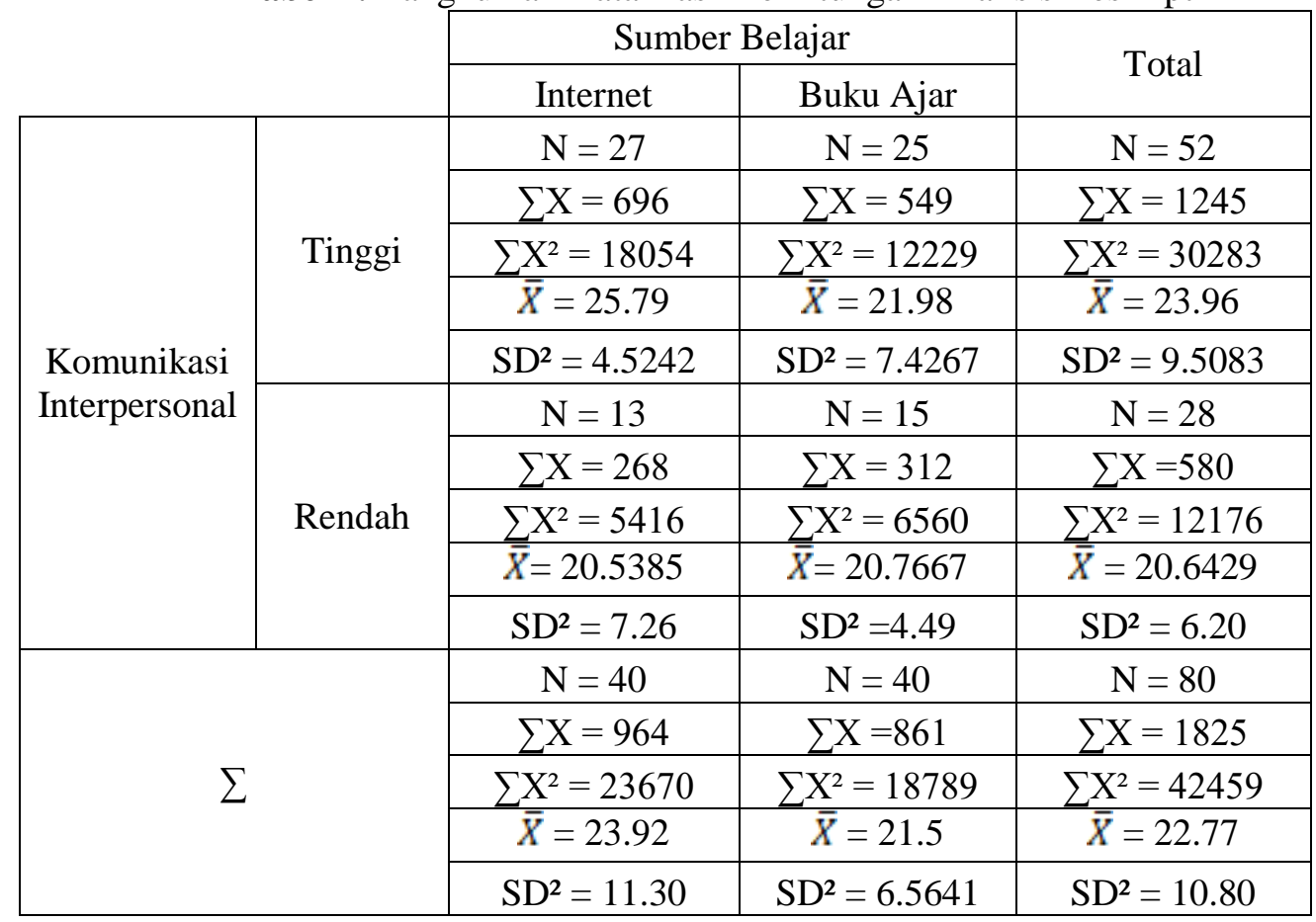


Tabel 3. Perhitungan harga-harga Jumlah Kuadrat (JK) untuk masing-masing variabel.

\begin{tabular}{|c|c|c|c|c|c|}
\hline Sumber Variasi & Df & RJK & $F_{\text {hitung }}$ & $\mathrm{F}_{\text {tabel }}$ & Keterangan \\
\hline Faktor A & 1 & 132.61 & 22.54 & 3.97 & Signifikan \\
\hline Faktor B & 1 & 189.64 & 32.23 & & Signifikan \\
\hline Interaksi (A x B) & 1 & 56.82 & 9.65 & & Signifikan \\
\hline Antar Kelompok & & & & & \\
\hline Dalam Kelompok & 76 & & & & \\
\hline Total & 79 & & & & \\
\cline { 1 - 2 } & & & &
\end{tabular}

\section{Hipotesis Pertama}

Perbedaan Hasil Belajar PKN Peserta

Didik yang Diajar Dengan Menggunakan Sumber belajar Dengan menggunakan internet Lebih Tinggi dengan Peserta Didik yang Diajar Dengan Menggunakan Sumber belajar Dengan menggunakan buku ajar. Hasil perhitungan analisis varians tentang rata-rata hasil belajar PKN peserta didik yang diajar dengan sumber belajar dengan menggunakan internet adalah sebesar 23.92 dan rata-rata hasil belajar PKN peserta didik yang diajar dengan sumber belajar dengan menggunakan buku ajar adalah sebesar 21.5 , didapat hasil analisis $F_{\text {hitung }}=22.54>\mathrm{F}_{\text {tabel }}$ $=3.97$, dengan demikian temuan penelitian ini menyimpulkan bahwa Ho ditolak dan $\mathrm{Ha}$ diterima. Hipotesis penelitian yang menyatakan bahwa Hasil belajar PKN peserta didik yang diajar dengan menggunakan sumber belajar dengan menggunakan internet lebih tinggi dibandingkan dengan peserta didik yang diajar dengan menggunakan sumber belajar dengan menggunakan buku ajar pada taraf signifikansi $\alpha=0.05$ telah teruji kebenarannya.

\section{Hipotesis Kedua}

Perbedaan Hasil Belajar PKN Peserta Didik yang Memiliki Komunikasi interpersonal Tinggi dengan Hasil Belajar PKN Peserta Didik yang Memiliki Komunikasi interpersonal Negatif. Hasil perhitungan analisis varians tentang rata-rata hasil belajar PKN peserta didik yang memiliki komunikasi interpersonal tinggi adalah sebesar 23.96 dan rata-rata hasil belajar PKN peserta didik yang memiliki komunikasi interpersonal rendah adalah sebesar 20.64, didapat hasil analisis $\mathrm{F}_{\text {hitung }}=32.23>\mathrm{F}_{\text {tabel }}=$ 3.97, dengan demikian temuan penelitian ini menyimpulkan bahwa hipotesis hasil belajar siswa yang memiliki komunikasi interpersonal tinggi lebih tinggi jika dibandingkan dengan hasil belajar siswa yang memiliki komunikasi interpersonal rendah pada taraf signifikansi $\alpha=$ 0.05 telah teruji kebenarannya.

\section{Hipotesis Ketiga}

Terdapat Interaksi antara Sumber belajar dengan Komunikasi interpersonal dalam Mempengaruhi Hasil Belajar PKN Peserta Didik. Hasil perhitungan analisis varians tentang rata-rata hasil belajar PKN peserta didik untuk setiap kelompok perlakuan adalah sebagai berikut: Rata-rata hasil belajar PKN peserta didik yang diajar dengan sumber belajar dengan menggunakan internet dan memiliki komunikasi interpersonal tinggi adalah sebesar 25.79, rata-rata hasil belajar PKN peserta didik yang diajar dengan sumber belajar dengan menggunakan internet dan memiliki komunikasi interpersonal rendah adalah sebesar 20.53, sedangkan rata-rata hasil belajar PKN peserta didik yang diajar dengan sumber belajar dengan menggunakan buku ajar dan memiliki komunikasi interpersonal tinggi adalah sebesar 21.98 dan rata-rata hasil belajar PKN peserta didik yang diajar dengan sumber belajar dengan menggunakan buku ajar dan memiliki komunikasi interpersonal rendah adalah sebesar 20.76. Hasil perhitungan Anava factorial $2 \times 2$ diperoleh hasil analisis $\mathrm{F}_{\text {hitung }}=12.65>\mathrm{F}_{\text {tabel }}=$ 3.97 , dengan demikian temuan penelitian yang menyatakan terdapat interaksi antara sumber belajar dengan komunikasi interpersonal dalam mempengaruhi hasil belajar PKN telah teruji kebenarannya pada taraf signifikansi 0.05. Interaksi antara sumber belajar dengan komunikasi interpersonal dalam mempengaruhi hasil belajar PKN peserta didik dapat divisualisasikan secara grafis pada gambar berikut. 


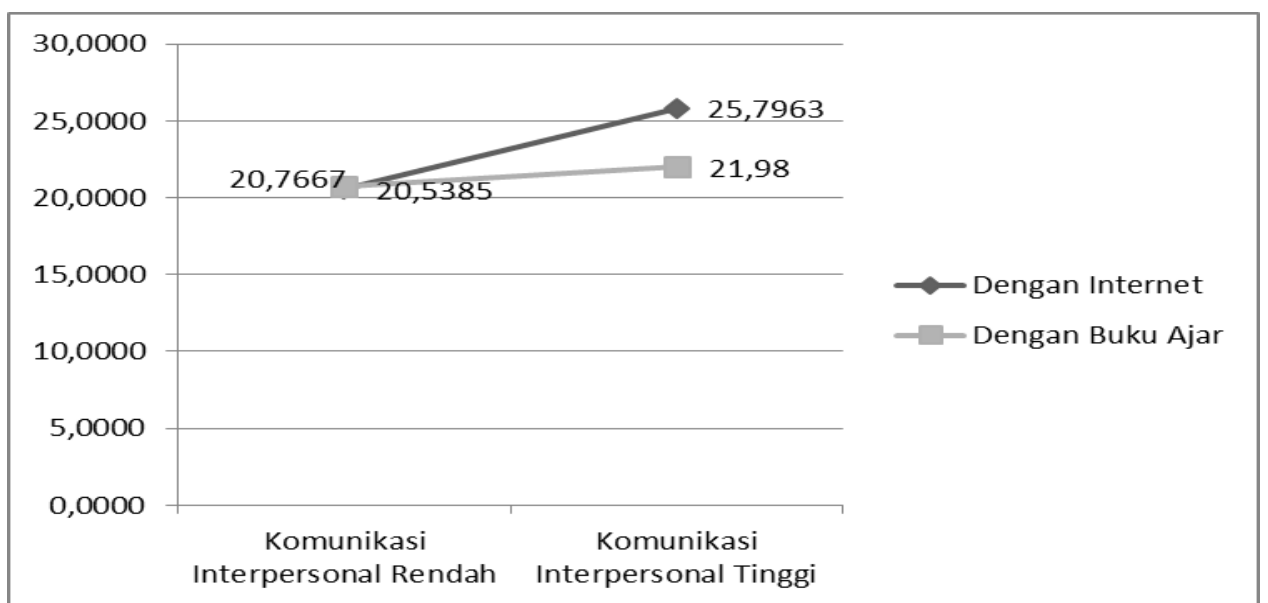

Gambar 1. Interaksi antara Sumber belajar dengan Komunikasi Interpersonal Dalam Mempengaruhi Hasil Belajar PKn Siswa

Berdasarkan hasil pengujian hipotesis ketiga yang menyatakan terdapat interaksi antara sumber belajar dengan komunikasi interpersonal dalam mempengaruhi hasil belajar PKN peserta didik, maka perlu dilakukan uji perbedaan antara dua proposisi untuk itu digunakan uji Lanjut Scheffe. Terdapat interaksi antara sumber belajar dengan komunikasi interpersonal siswa dalam mempengaruhi hasil belajar PKN siswa, akan tetapi sumber belajar dengan menggunakan internet lebih dominan dibandingkan dengan sumber belajar dengan menggunakan buku ajar. Dengan kata lain semakin baik sumber belajar yang digunakan oleh guru dalam menyampaikan materi pembelajaran, maka semakin tinggi hasil belajar PKN siswa. Selain itu faktor komunikasi interpersonal juga perlu diperhatikan karena terbukti bahwa komunikasi interpersonal berpengaruh terhadap hasil belajar PKN siswa. Hasil pengujian lanjut dengan menggunakan Uji Scheffe dapat dilihat pada tabel berikut.

Tabel 4. Ringkasan Hasil Perhitungan Uji Scheffe

\begin{tabular}{|c|c|c|c|c|}
\hline \multirow{2}{*}{ No. } & \multirow{2}{*}{ Kelompok } & \multicolumn{2}{|c|}{ Uji Scheffe } & \multirow{2}{*}{ Keterangan } \\
\cline { 3 - 3 } & & Fh & Ft $=0.05$ & \\
\hline 1 & A1 dengan A2 & 5.84 & \multirow{2}{*}{2.73} & Signifikan \\
\hline 2 & B1 dengan B2 & 5.83 & & Signifikan \\
\hline 3 & A1B1 dengan A2B1 & 5.66 & & Signifikan \\
\hline 4 & A1B1 dengan A2B2 & 6.43 & & Signifikan \\
\hline 5 & A1B1 dengan A1B2 & 6.42 & & Signifikan \\
\hline 6 & A1B2 dengan A2B1 & 1.71 & & T. Signifikan \\
\hline 7 & A1B2 dengan A2B2 & 0.24 & & T. Signifikan \\
\hline 8 & A2B1 dengan A2B2 & 1.59 & & T. Signifikan \\
\hline
\end{tabular}

Perhitungan Uji Scheffe didapat $F_{h}=$ 5.84 lebih tinggi dari $\mathrm{F}_{\mathrm{t}}=2.73$ pada taraf signifikansi $\alpha=0.05$. Dengan demikian untuk uji lanjut Ho ditolak dan Ha diterima. Berarti hasil belajar PKN siswa yang diajar dengan pembelajaran dengan menggunakan internet lebih tinggi dibandingkan dengan siswa yang diajar dengan sumber belajar dengan menggunakan buku ajar.

Perhitungan Uji Scheffe didapat $\mathrm{F}_{\mathrm{h}}=$ 5.83 lebih tinggi dari $F_{t}=2.73$ pada taraf signifikansi $\alpha=0.05$. Dengan demikian untuk uji lanjut Ho ditolak dan Ha diterima. Berarti hasil belajar PKN siswa yang memiliki komunikasi interpersonal tinggi lebih tinggi dibandingkan dengan siswa yang siswa yang memiliki komunikasi interpersonal rendah.

Perhitungan Uji Scheffe didapat Fh $=$ 5.6689 lebih tinggi dari $\mathrm{Ft}=2.73$ pada taraf signifikansi $\alpha=0.05$. Dengan demikian untuk uji lanjut Ho ditolak dan Ha diterima. Berarti hasil belajar PKN siswa yang diajar dengan 
pembelajaran dengan menggunakan internet dan memiliki komunikasi interpersonal tinggi lebih tinggi dibandingkan dengan siswa yang diajar dengan sumber belajar dengan menggunakan buku ajar dan memiliki komunikasi interpersonal tinggi.

Perhitungan Uji Scheffe didapat $\mathrm{F}_{\mathrm{h}}=$ 6.43lebih tinggi dari $F_{t}=2.73$ pada taraf signifikansi $\alpha=0.05$. Dengan demikian untuk uji lanjut Ho ditolak dan Ha diterima. Berarti hasil belajar PKN siswa yang diajar dengan pembelajaran dengan menggunakan internet dan memiliki komunikasi interpersonal tinggi lebih tinggi dibandingkan dengan siswa yang diajar dengan sumber belajar dengan menggunakan buku ajar dan memiliki komunikasi interpersonal rendah.

Perhitungan Uji Scheffe didapat $\mathrm{F}_{\mathrm{h}}=$ 6.42 lebih tinggi dari $\mathrm{F}_{\mathrm{t}}=2.73$ pada taraf signifikansi $\alpha=0.05$. Dengan demikian untuk uji lanjut Ho ditolak dan Ha diterima. Berarti hasil belajar PKN siswa yang diajar dengan pembelajaran dengan menggunakan internet dan memiliki komunikasi interpersonal tinggi lebih tinggi dibandingkan dengan siswa yang diajar dengan sumber belajar dengan menggunakan internet dan memiliki komunikasi interpersonal rendah.

Perhitungan Uji Scheffe didapat Fh = 1.71 lebih rendah dari $\mathrm{Ft}=2.73$ pada taraf signifikansi $\alpha=0.05$. Dengan demikian untuk uji lanjut Ho diterima dan Ha ditolak. Berarti hasil belajar PKN siswa yang diajar dengan pembelajaran dengan menggunakan internet dan memiliki komunikasi interpersonal rendah lebih rendah dibandingkan dengan siswa yang diajar dengan sumber belajar dengan menggunakan buku ajar dan memiliki komunikasi interpersonal tinggi.

Perhitungan Uji Scheffe didapat $\mathrm{Fh}=$ 0.24 lebih rendah dari $\mathrm{Ft}=2.73$ pada taraf signifikansi $\alpha=0.05$. Dengan demikian untuk uji lanjut Ho ditolak dan Ha diterima. Berarti hasil belajar PKN siswa yang diajar dengan pembelajaran dengan menggunakan internet dan memiliki komunikasi interpersonal rendah lebih rendah dibandingkan dengan siswa yang diajar dengan sumber belajar dengan menggunakan buku ajar dan memiliki komunikasi interpersonal rendah.

Perhitungan Uji Scheffe didapat Fh = 1.59 lebih rendah dari $\mathrm{Ft}=2.73$ pada taraf signifikansi $\alpha=0.05$. Dengan demikian untuk uji lanjut Ho diterima dan Ha ditolak. Berarti hasil belajar PKN siswa yang diajar dengan pembelajaran dengan menggunakan buku ajar dan memiliki komunikasi interpersonal tinggi lebih rendah dibandingkan dengan siswa yang diajar dengan sumber belajar dengan menggunakan buku ajar dan memiliki komunikasi interpersonal rendah.

\section{PEMBAHASAN}

Hasil penelitian menunjukkan bahwa hasil belajar PKN peserta didik yang diajar dengan menggunakan sumber belajar dengan menggunakan internet lebih tinggi jika dibandingkan dengan peserta didik yang diajar dengan menggunakan sumber belajar dengan menggunakan buku ajar. Hal ini diidentifikasi dari nilai rata-rata hasil belajar PKN peserta didik yang diajar dengan menggunakan sumber belajar dengan menggunakan internet lebih tinggi jika dibandingkan dengan nilai rata-rata hasil belajar PKN peserta didik yang diajar dengan menggunakan sumber belajar dengan menggunakan buku ajar. Hal ini menunjukkan bahwa untuk mengajarkan materi PKN lebih baik menggunakan sumber belajar dengan menggunakan internet jika dibandingkan dengan sumber belajar dengan menggunakan buku ajar.

Hal ini karena setiap sumber belajar adalah baik untuk setiap kondisi pembelajaran. Setiap sumber belajar memiliki karakteristikkarakteristik tersendiri dalam pelaksanaan dan hal itulah yang membedakan setiap sumber belajar yang satu dengan sumber belajar yang lainnya. Sumber belajar yang tepat adalah sumber belajar yang efektif dan efisien dalam mencapai tujuan pembelajaran. Tujuan pembelajaran akan mudah dicapai jika peserta didik termotivasi untuk belajar. Selain itu, guru sebagai tenaga pengajar dan juga lingkungan siswa juga turut serta dalam mempengaruhi proses pembelajaran. Lingkungan belajar yang nyaman dan menyenangkan akan dapat meningkatkan hasil belajar siswa yakni dengan meningkatkan komunikasi interpersonal mereka sehingga pada akhirnya akan membantu mereka untuk mencapai tujuan pembelajaran selama proses pembelajaran berlangsung.

Sumber belajar dengan menggunakan internet adalah sebuah sumber belajar dimana proses belajar siswa dimulai dengan mengeksplorasi internet. Dari sini maka siswa akan aktif dalam proses kegiatan mencari atau 'berlayar" di dunia internet materi pelajaran yang sedang mereka teliti. Disini mereka akan mengembangkan kemampuan memecahkan 
masalah mereka dan bagaimana bertukar pikiran. Sedangkan pada sumber belajar dengan menggunakan buku ajar siswa dituntut untuk menemukan masalah. Dan hal ini tentu saja mengakibatkan peserta didik tidak mencapai tujuan pembelajaran, karena dalam proses belajar mereka, peserta didik tidak memiliki tuntunan. Oleh karena itu Sumber belajar dengan menggunakan internet adalah lebih baik digunakan dalam pembelajaran PKN jika dibandingkan dengan sumber belajar dengan menggunakan buku ajar. Hal ini tentu saja sejalan dengan pendapat Rahardjo (2002) yang menyatakan bahwa manfaat internet bagi pendidikan adalah dapat menjadi akses kepada sumber informasi, akses kepada nara sumber, dan sebagai media kerjasama. Sehingga penggunaan internet yang intensif dan tepat guna akan mempunyai korelasi yang signifikan terhadap prestasi belajar.

Internet sebagai sumber belajar yang dimanfaatkan dapat memberikan fasilitas belajar bagi siswa karena internet adalah jaringan informasi komputer mancanegara yang berkembang sangat pesat dan pada saat ini dapat dikatakan sebagai jaringan informasi terbesar di dunia, sehingga sudah seharusnya para profesional mengenal manfaat apa yang dapat diperoleh melalui jaringan ini. Internet diharapkan mampu memberikan dukungan bagi terselenggaranya proses komunikasi interaktif antara guru dengan siswa. Hal yang serupa juga dikemukakan oleh Rahardjo (2002) yang menyatakan bahwa manfaat internet bagi pendidikan adalah dapat menjadi akses kepada sumber informasi, akses kepada nara sumber, dan sebagai media kerjasama. Sehingga penggunaan internet yang intensif dan tepat guna akan mempunyai korelasi yang signifikan terhadap prestasi belajar. Pendapat ini tentu saja sangat mendukung hasil penelitian ini.

Hasil penelitian menunjukkan bahwa terdapat interaksi antara sumber belajar dengan komunikasi interpersonal dalam mempengaruhi hasil belajar PKN. Hasil belajar PKN peserta didik yang diajar dengan menggunakan sumber belajar dengan menggunakan internet dan memiliki komunikasi interpersonal yang positif memiiki hasil belajar PKN yang positif lebih tinggi jika dibandingkan dengan peserta didik yang diajar dengan menggunakan sumber belajar dengan menggunakan internet dan memiliki komunikasi interpersonal yang rendah.
Selain sumber belajar yang baik dan dijalankan oleh teaga profesional, untuk mencapai hasil pembelajaran yang diinginkan, maka harus tercipta proses komunikasi yang baik selama proses pembelajaran berlangsung. Hal ini karena komunikasi adalah suatu proses dimana dua orang atau lebih membentuk atau melakukan pertukaran informasi dengan satu sama lainnya, yang pada gilirannya akan tiba pada saling pengertian yang mendalam (Cangara, 2004). Dengan demikian jika terciptanya komunikasi yang baik, maka diharapkan pertukaran informasi antara seorang dengan yang lainnya akan berjalan lancar, yang pada akhirnya akan tiba pada saling pengertian yang mendalam.

Salah satu bentuk komunikasi yang berlangsung terhadap diri manusia adalah komunikasi interpersonal. Komunikasi interpersonal adalah penyampaian pesan oleh satu orang dan penerimaan pesan oleh orang lain atau sekelompok kecil orang, dengan berbagai dampaknya dan dengan peluang untuk memberikan umpan balik segera (Devito, 2009). Komunikasi interpersonal adalah komunikasi antara orang-orang secara tatap muka, yang memungkinkan setiap pesertanya menangkap reaksi orang lain secara langsung, baik secara verbal atau nonverbal.

Komunikasi interpersonal yag baik akan dapat memfasilitasi seseorang untuk terlibat dalam proses komunikasi, jadi kedua belah pihak harus sama-sama mempunyai kegiatan, aksi tertentu sehingga memberi tanda bahwa mereka sedang berkomunikasi. Hasil penelitian menujukkan bahwa terdapat interaksi antara sumber belajar dengan komunikasi interpersonal dalam mempengaruhi hasil belajar PKN. Hal ini menunjukkan untuk mencapai hasil belajar yang baik, maka dalam penggunaan sumber belajar diperlukan komunikasi interpersonal yang tinggi. Adanya perbedaan komunikasi interpersonal siswa yang memiliki komunikasi interpersonal tinggi dengan siswa yang memiliki komunikasi interpersonal rendah memberikan pengaruh yang berbeda terhadap perolehan hasil belajar siswa.

Siswa dengan komunikasi interpersonal tinggi dapat mengetahui suatu kejadian atau peristiwa bahkan dapat mengembangkan pengetahuannya, yakni belajar dari pengalamannya maupun melalui informasi yang mereka terima dari lingkungan sekitarnya, yang pada gilirannya akan memberikan suasana 
saling pengertian yang mendalam sedangkan siswa yang memiliki kemampuan interpersonal rendah tidak memiliki kemampuan dalam membuat kebersamaan atau membangun kebersamaan antara dua orang atau lebih dalam menemukan solusi atau pemecahan masalah pembelajaran yang dihadapinya. Siswa yang memiliki kemampuan komunikasi interpersonal tinggi yang diajar dengan menggunakan sumber belajar internet cenderung lebih aktif dalam pembelajaran PKn sehingga dapat mencapai hasil belajar yang optimal yang sesuai dengan tujuan pembelajaran. Sedangkan bagi siswa yang memiliki kemampuan komunikasi interpersonal rendah yang diajar dengan penggunaan sumber belajar internet yang menuntut keaktifan siswa dalam setiap kegiatan pembelajaran, maka siswa yang memiliki komunikasi interpersonal rendah akan merasa kesulitan dalam belajar. Hal ini disebabkan karena siswa yang memiliki komunikasi interpersonal rendah merasa kesulitan dalam membentuk atau melakukan pertukaran informasi satu sama lainnya.

Siswa yang memiliki komunikasi interpersonal tinggi yang diajar dengan pengunaan sumber belajar dari buku ajar akan mengalami kebosanan tersendiri karena hanya mendengarkan informasi dari guru saja, sementara siswa yang memiliki kemampuan interpersonal tinggi dapat mengetahui suatu kejadian atau peristiwa bahkan dapat mengembangkan pengetahuannya, yakni belajar dari pengalamannya maupun melalui informasi yang mereka terima dari lingkungan sekitarnya. Sedangkan bagi siswa yang memiliki komunikasi interpersonal rendah yang diajar dengan pembelajaran yang menggunakan buku ajar dapat mengalami kemudahan dalam belajar, karena mereka tinggal menerima apa yang disampaikan oleh gurunya tanpa adanya upaya membangun kebersamaan antara dua orang atau lebih dalam menemukan solusi atau pemecahan masalah pembelajaran yang dihadapinya, sehingga dimungkinkan hasil belajarnya akan lebih baik.

\section{PENUTUP}

Berdasarkan hasil pengujian hipotesis seperti yang telah diuraikan, penelitian ini menyimpulkan bahwa: (1) Hasil belajar PKN Peserta Didik yang Diajar Dengan Menggunakan Sumber belajar Dengan Menggunakan internet Lebih Tinggi Dibandingkan dengan Peserta Didik yang
Diajar Menggunakan Sumber belajar Dengan Menggunakan Buku Ajar; (2) Hasil belajar PKN Peserta Didik yang Memiliki Komunikasi Interpersonal Positif Lebih Tinggi Dibandingkan dengan Hasil Belajar PKN Peserta Didik yang Memiliki Komunikasi Interpersonal Negatif; dan (3) Terdapat interaksi antara Sumber belajar dan Komunikasi Interpersonal Dalam Mempengaruhi Hasil Belajar PKN Peserta Didik.

\section{DAFTAR PUSTAKA}

AECT. 2004. Definisi Teknologi Pendidikan. (Diterjemahkan oleh PAU di Universitas Terbuka). Jakarta : PT. Grafindo Persada.

Adaptasi dari : Depdiknas. 2004. Pedoman Merancang Sumber Belajar. Jakarta

Ahmadi dan Supriono, W. 2004. Psikologi Belajar. Jakarta : Raja Grafindo Persada Amnah. 2007. Pengaruh Strategi Pembelajaran Advance Organizer dan Komunikasi Interpersonal terhadap hasil belajar Biologi siswa SMA Negeri 1 Kecamatan Binjai. Tesis. Medan : Program Pasca Sarjana Universitas Negeri Medan

Atmadi, A.dkk. 2000. Transformasi Pendidikan Memasuki Millenium Ketiga.

Yogyakarta : Kanisius

Cangara, H. 2004. Pengantar Ilmu Komunikasi Cetakan V. Jakarta : Raja Grafindo

Daradjat, Zakiah. 2001. Metode Khusus Pengajaran Agama Islam. Jakarta : Bumi Aksara

Degeng. 2001. Ilmu Pengajaran Taksonomi Variabel. Jakarta : Depdikbud Dikti P2LPTK

Dick, W. \& Carey, L. 2005. The Systematic Design of Instruction Fourth Edition NewYork : Harper Collin College Publisher

Dimyati dan Mudjiono. 2006. Belajar dan Pembelajaran. Jakarta: Rineka Cipta

Devito, J.A. 2009. The International Communication. New York : Harper and Row Publisher

2011. Komunikasi Antar Manusia Edisi Kelima Alih Bahasa Maulana Agus. Tangerang Selatan : Karisma

Djamarah, Syaiful B dan Zain, Aswan. 2002. Strategi Belajar Mengajar. Jakarta : Rineka Cipta

Effendy, O.U. 2003. Dinamika Komunikasi. Bandung : CV. Remadja Karya 
Fachrunnisa, O. 2008. Identifikasi Komunikasi Non Verbal di Organisasi. Ekobis Vol.9, Januari $2008: 57$ - 67

Fudyartanto, R.B. S. 2002. Psikologi Pendidikan dengan Pendekatan Baru. Yogyakarta : Global Pustaka Utama

Gagne, R.M. 2002. The Condition of Learning and Theory of Instruction (4 ${ }^{\text {th }}$ edition). New York: Hott Rinehart and Winston

Hamalik, Oemar. 2001. Proses Belajar Mengajar. Jakarta: Bumi Aksara

-------------.2001. Perencanaan Pengajaran Berdasarkan Pendekatan Sistem. Jakarta : Bumi Aksara

------------------. 2001. Kurikulum dan Pengajaran. Jakarta : Bumi Aksara

Hamid, A. 2009. Teori Belajar dan Pembelajaran. Medan : PPs Unimed

Hasan, I.M. 2003. Pokok-pokok Materi Pendidikan Pancasila. Jakarta : Raja Grafindo Persada

Hendra. 2011. Penggunaan media pembelajaran interaktif dan komunikasi interpersonal terhadap Hasil belajar kimia siswa SMA Swasta Sutomo 2 Medan. Tesis. Program Pasca Sarjana Unversitas Negeri Medan

Julkifli. 2008. Pengaruh Strategi Pembelajaran Elaborasi dan Komunikasi Interpersonal terhadap hasil belajar PPKn MTs Swasta Nurul Hikmah Tinjoan Kabupaten Simalungun. Tesis. Medan : Program Pasca Sarjana Unversitas Negeri Medan

Lubis, F. W. 2008. Peranan Komunikasi dalam Organisasi. Jurnal Harmoni Sosial, Volume II No.2 Januari 2008 : 53 - 57

Miarso, Yusufhadi, dkk. 1996. Teknologi Komunikasi Pendidikan. Jakarta : Rajawali

Muhammad, A. 2007. Komunikasi Organisasi. Yogyakarta : Bumi Aksara

Nawawi Hadari. 2004. Meningkatkan Mutu Pembelajaran di Sekolah. Makalah. Semarang : Depdiknas

Pidarta, Made. 2003. Landasan Kependidikan, Stimulus Hum Pendidikan Bercorak Indonesia. Jakarta : Rineka Cipta
Rakmat, J. 2004. Psikologi Komunikasi. Bandung : PT. Remaja Rosdakarya

Sagala, Syaiful. 2007. Konsep dan Makna Pembelajaran. Bandung : Alfabeta

Sardiman, A.M. 2003. Interaksi dan Motivasi Belajar Mengajar. Jakarta : Raja Grafindo

Sanjaya. 2002. E- education : Konsep Teknologi dan Aplikasi Internet Pendidikan. Jakarta : Penerbit Andi

Sri Handarini. 2003. Pengaruh Komunikasi Interpersonal Tutor Terhadap Motivasi Peserta Didik Di Kelompok Belajar Keaksaraan Fungsional (Kejar KF) Binaan Balai Pengembangan Pendidikan Luar Sekolah Dan Pemuda (BPPLSP). Tesis. Medan : Program Pasca Sarjana Universitas Negeri Medan

Sumantri. 2001. Menggagas Pembaruan Pendidikan IPS. Bandung : Remaja Rosdakarya

Sumarsono. S, dkk. 2002. Pendidikan Kewarganegaraan. Jakarta : Gramedia Pustaka Utama

Sudjana, N. 2004. Dasar-Dasar Proses Belajar Mengajar. Bandung : Sinar Baru Algensindo

Seels, B and Richey,C.1994. Teknologi Pembelajaran. (Diterjemahkan oleh Yusufhadi Miarso, dkk. Jakarta : Universitas Negeri Jakarta

Solihatin Etin. 2012. Strategi Pembelajaran $P P K N$. Jakarta : Bumi Aksara

Soyomukti, Nurani. 2010. Pengantar Ilmu Komunikasi. Yogyakarta : Ar- Ruzz Media

Tamburaka, R.R. 2001. Pendidikan Pancasila Tinjauan Filsafat Pancasila serta Etika Profesi Berdasarkan Pancasila. Jakarta : Pustaka Jaya

Tubs, Stewart L \& Moss, Sylvia. 2003. Human Communication Principle and Context. New York : Mc. Graw Hill

Tim Edukom. 2006. Pengenalan Internet. Bandung : Cemerlang Abadi 